Article

\title{
Three New Cytotoxic Steroidal Alkaloids from Sarcococca hookeriana
}

\author{
Kang He ${ }^{1,+}$, Jinxi Wang ${ }^{2,+}$, Juan Zou ${ }^{1}$, Jichun $\mathrm{Wu}^{1}$, Shaojie Huo ${ }^{1}$ and Jiang Du ${ }^{1, *}$ \\ 1 The Key Laboratory of Miao Medicine of Guizhou Province, Guiyang College of Traditional Chinese \\ Medicine, Guiyang 550025, Guizhou, China; hekang0851@163.com (K.H.); zoujuan@hotmail.com (J.Z.); \\ wujichun2018@sina.com (J.W.); 15038115764@163.com (S.H.) \\ 2 The Ethnical Medicine Research Institute of Qian Dong Nan Miao and Dong Autonomous Prefecture, \\ Kaili 556000, Guizhou, China; 15185660328@163.com \\ * Correspondence: dujang.gz@163.com; Tel.: +86-871-8830-8060 \\ + These authors contributed equally to this work and are co-first authors.
}

Received: 13 April 2018; Accepted: 10 May 2018; Published: 15 May 2018

\begin{abstract}
Three new steroidal alkaloids with an unusual $3 \alpha$ tigloylamide group, named sarchookloides A-C (1-3), were isolated along with four known compounds (4-7) from the roots of Sarcococca hookeriana. Their structures and relative configuration were elucidated on the basis of spectroscopic methods including MS, UV, IR, 1D, and 2D NMR data. The isolated compounds were evaluated for their cytotoxicity against five human cancer cell lines: Hela, A549, MCF-7, SW480, and CEM in vitro. All three amide substituted steroidal alkaloids exhibited significant cytotoxic activities with $\mathrm{IC}_{50}$ values of $1.05-31.83 \mu \mathrm{M}$.
\end{abstract}

Keywords: Sarcococca hookeriana; sarchookloides A-C; steroidal alkaloid; cytotoxicity

\section{Introduction}

The genus Sarcococca (Buxaceae) includes about 20 species, eight of which are found in China [1]. Some of them are used in TCM and traditional folk medicine to treat stomach pain, rheumatism, swollen sore throat, and bruises [2-4]. Previous studies on this genus revealed that the steroidal alkaloids were the main chemical components, and possessed a range of bioactivities (e.g., cholinesterase inhibiting, antitumor, antibacterial, antiulcer, antiplasmodial, and antidiabetic) [5-20]. For the search of bioactive metabolites from this genus, our previous investigation on Sarcococca ruscifolia resulted in the discovery of two new steroidal alkaloids [16]. As part of our continuous exploration of active alkaloids, three new steroidal alkaloids, namely sarchookloides A-C (1-3) along with four known compounds, pachysamine G (4), pachysamine $H$ (5), sarcovagine B (6), and pachyaximine A (7) (Figure 1), were isolated from the roots of Sarcococca hookeriana. The new compounds, sarchookloides A-C (1-3), were shown to possess a $3 \alpha$ substituent, which has rarely been reported [17]. The cytotoxicity assay on human cancer cell lines Hela, A549, MCF-7, SW480, and CEM in vitro demonstrated that these steroidal alkaloids exhibited potent antitumor activities. This paper describes the isolation, structure elucidation, and cytotoxicity activities of the isolates.

\section{Results and Discussion}

\subsection{Structure Elucidation of Compounds}

Compound 1 showed a quasi-molecular ion peak $[\mathrm{M}+\mathrm{H}]^{+}$at $m / z 461.3731$ (calculated to be 461.3738) in the HR-ESI-MS (spectrum showed in Supplementary material), which corresponds to 
the molecular formula $\mathrm{C}_{28} \mathrm{H}_{48} \mathrm{~N}_{2} \mathrm{O}_{3}$. The IR spectrum showed absorption bands at 3424 (hydroxyl group), 1662 (amide carbonyl group), and 1623 (double bond) $\mathrm{cm}^{-1}$. The ${ }^{1} \mathrm{H}$ and ${ }^{13} \mathrm{C}$ NMR (DEPT) spectra (Table 1) displayed 28 carbon resonances due to four quaternary carbons, 10 methines, seven methylenes, and seven methyl groups, which revealed one amide carbonyl group and one double bond. The presence of five methyl signals $\left[\delta_{\mathrm{H}} 0.67(3 \mathrm{H}, \mathrm{s}, \mathrm{H}-18), 1.21(3 \mathrm{H}, \mathrm{s}, \mathrm{Me}-19), 0.92\right.$ $(3 \mathrm{H}, \mathrm{d}, J=6.4 \mathrm{~Hz}, \mathrm{Me}-21), 2.23(6 \mathrm{H}, \mathrm{s}, \mathrm{N}, \mathrm{N}$-dimethyl $)]$ and one nitric proton signal $\left[\delta_{\mathrm{H}} 6.09(1 \mathrm{H}, \mathrm{d}\right.$, $J=5.1 \mathrm{~Hz}, \mathrm{NH}-3)]$ in the ${ }^{1} \mathrm{H}$ NMR $\left(\mathrm{CDCl}_{3}\right)$ spectrum in combination with 2D NMR data suggested that compound 1 belongs to the $20 \alpha$-dimethylamino-3-amino- $5 \alpha$-pregnane type steroidal alkaloids [21].

Table 1. ${ }^{1} \mathrm{H}(600 \mathrm{MHz})$ and ${ }^{13} \mathrm{C}(150 \mathrm{MHz})$ NMR data of compounds $1-3$ in $\mathrm{CDCl}_{3}$.

\begin{tabular}{|c|c|c|c|c|c|c|}
\hline \multirow{2}{*}{ Position } & \multicolumn{2}{|l|}{1} & \multicolumn{2}{|l|}{2} & \multicolumn{2}{|c|}{3} \\
\hline & $\delta_{\mathrm{H}}(J$ in $\mathrm{Hz})$ & $\delta_{\mathrm{C}}$ & $\delta_{\mathrm{H}}(J$ in $\mathrm{Hz})$ & $\delta_{\mathrm{C}}$ & $\delta_{\mathrm{H}}(J$ in $\mathrm{Hz})$ & $\delta_{\mathrm{C}}$ \\
\hline 1 & $1.67,1.69, \mathrm{~m}$ & 44.2 & $1.16,1.87, \mathrm{~m}$ & 40.6 & $0.95,1.56, \mathrm{~m}$ & 33.6 \\
\hline 2 & 3.88, ddd $(13.4,6.7,6.8)$ & 69.0 & 3.97, brs $\left(\mathrm{W}_{1 / 2} 14.8\right)$ & 69.6 & $1.64,1.71, \mathrm{~m}$ & 26.2 \\
\hline 3 & 3.99, ddd $(7.8,6.8,5.1)$ & 58.4 & $4.03, \mathrm{~m}$ & 50.8 & $4.14, \mathrm{~m}$ & 44.8 \\
\hline 4 & $3.78, \mathrm{dd},(7.8,3.9)$ & 76.3 & $1.23,2.04, \mathrm{~m}$ & 28.8 & $1.39,1.55, \mathrm{~m}$ & 33.0 \\
\hline 5 & $1.26, \mathrm{~m}$ & 45.5 & $1.07, \mathrm{~m}$ & 41.8 & $1.11, \mathrm{~m}$ & 41.5 \\
\hline 6 & $1.41,1.79, \mathrm{~m}$ & 24.4 & $1.48,1.85, \mathrm{~m}$ & 27.9 & $1.48,1.87, \mathrm{~m}$ & 27.8 \\
\hline 7 & $1.01,1.77, \mathrm{~m}$ & 32.2 & $0.91,1.68, \mathrm{~m}$ & 32.1 & $0.88,1.68, \mathrm{~m}$ & 32.1 \\
\hline 8 & $1.37, \mathrm{~m}$ & 35.3 & $1.39, \mathrm{~m}$ & 34.9 & $1.36, \mathrm{~m}$ & 35.5 \\
\hline 9 & $0.71, \mathrm{~m}$ & 57.0 & $1.05, \mathrm{~m}$ & 56.8 & $0.68, \mathrm{~m}$ & 54.7 \\
\hline 10 & - & 36.0 & - & 35.9 & - & 36.2 \\
\hline 11 & $1.35,1.44, \mathrm{~m}$ & 21.0 & $1.30,1.50, \mathrm{~m}$ & 21.0 & $1.22,1.51, \mathrm{~m}$ & 20.9 \\
\hline 12 & $1.12,1.90, \mathrm{~m}$ & 39.9 & $1.09,1.90, \mathrm{~m}$ & 40.0 & $1.08,1.88, \mathrm{~m}$ & 40.0 \\
\hline 13 & - & 42.1 & - & 41.8 & - & 41.5 \\
\hline 14 & $1.03, \mathrm{~m}$ & 56.8 & $0.66, \mathrm{~m}$ & 55.6 & $1.04, \mathrm{~m}$ & 56.8 \\
\hline 15 & $1.10,1.60, \mathrm{~m}$ & 24.2 & $1.06,1.58, \mathrm{~m}$ & 24.2 & $1.03,1.57, \mathrm{~m}$ & 24.2 \\
\hline 16 & $1.50,1.84, \mathrm{~m}$ & 27.9 & $1.35,1.44, \mathrm{~m}$ & 28.4 & $1.19, \mathrm{~m}$ & 28.6 \\
\hline 17 & $1.34, \mathrm{~m}$ & 54.8 & $1.32, \mathrm{~m}$ & 54.8 & $1.33, \mathrm{~m}$ & 54.7 \\
\hline 18 & $0.67, \mathrm{~s}$ & 12.6 & $0.64, \mathrm{~s}$ & 12.6 & $0.63, \mathrm{~s}$ & 12.5 \\
\hline 19 & $1.21, \mathrm{~s}$ & 19.3 & $1.02, \mathrm{~s}$ & 14.5 & $0.79, \mathrm{~s}$ & 11.6 \\
\hline 20 & $2.50, \mathrm{~m}$ & 61.6 & $2.45, \mathrm{~m}$ & 61.6 & $2.45, \mathrm{~m}$ & 61.6 \\
\hline 21 & $0.92, \mathrm{~d},(6.4)$ & 10.2 & $0.89, \mathrm{~d},(6.4)$ & 10.2 & $0.88, \mathrm{~d},(6.4)$ & 10.3 \\
\hline $\mathrm{NMe} 2$ & $2.23, \mathrm{~s}$ & 39.8 & $2.20, \mathrm{~s}$ & 39.9 & $2.20, \mathrm{~s}$ & 39.9 \\
\hline $\mathrm{C}=\mathrm{O}$ & - & 170.6 & - & 169.2 & - & 168.8 \\
\hline $2^{\prime}$ & - & 131.4 & - & 132.2 & - & 132.6 \\
\hline $3^{\prime}$ & $6.45, \mathrm{q},(6.9)$ & 132.1 & $6.37, \mathrm{q},(6.9)$ & 130.8 & $6.36, \mathrm{q},(6.9)$ & 130.2 \\
\hline $4^{\prime}$ & $1.76, d,(6.9)$ & 14.3 & $1.75, \mathrm{~d},(6.9)$ & 14.2 & $1.73, \mathrm{~d},(6.9)$ & 14.1 \\
\hline $5^{\prime}$ & $1.84, \mathrm{~s}$ & 12.6 & $1.84, \mathrm{~s}$ & 12.7 & $1.83, \mathrm{~s}$ & 12.7 \\
\hline $\mathrm{NH}$ & $6.09, \mathrm{~d},(5.1)$ & - & $5.82, \mathrm{~d},(7.4)$ & - & $5.93, d,(6.6)$ & - \\
\hline $2-\mathrm{OH}$ & $2.84, \mathrm{~d},(7.2)$ & - & - & - & - & - \\
\hline $4-\mathrm{OH}$ & $4.40, \mathrm{~d},(3.0)$ & - & - & - & - & - \\
\hline
\end{tabular}

The presence of two methyl $\left[\delta_{\mathrm{H}} 1.76\left(3 \mathrm{H}, \mathrm{d}, J=6.9 \mathrm{~Hz}, \mathrm{H}-4^{\prime}\right), 1.84\left(3 \mathrm{H}, \mathrm{s}, \mathrm{H}-5^{\prime}\right)\right]$ and an olefinic proton $\left[\delta_{\mathrm{H}} 6.45\left(1 \mathrm{H}, \mathrm{q}, J=6.9 \mathrm{~Hz}, \mathrm{H}-3^{\prime}\right)\right]$ signals in the ${ }^{1} \mathrm{H}$ NMR spectrum together with two methyl $\left[\delta_{\mathrm{C}} 14.3\left(\mathrm{C}-4^{\prime}\right), 12.6\left(\mathrm{C}-5^{\prime}\right)\right]$, one double bond $\left[\delta_{\mathrm{C}} 131.4\left(\mathrm{C}-2^{\prime}\right), 132.1\left(\mathrm{C}-3^{\prime}\right)\right]$, and one carbonyl [ $\delta_{\mathrm{C}} 170.6$ $\left.\left(\mathrm{C}-1^{\prime}\right)\right]$ signals in the ${ }^{13} \mathrm{C}$ NMR spectrum led to the deduction of a tigloyl moiety, which was supported by the ${ }^{1} \mathrm{H}-{ }^{1} \mathrm{H}$ COSY-correlated signal of $\mathrm{H}-4^{\prime} / \mathrm{H}-3^{\prime}$ and the HMBC correlations of $\mathrm{H}-5^{\prime} / \mathrm{C}-3^{\prime}, \mathrm{C}-1^{\prime}$ and $\mathrm{H}-3^{\prime} / \mathrm{C}-1^{\prime}$ (Figure 2). Furthermore, the HMBC correlations of NH/C-2' (Figure 2) proposed that the location of the tigloyl group was at N-3. In addition, the two hydroxyl groups assigned at the $\mathrm{C}-2\left(\delta_{\mathrm{C}} 69.0\right)$ and C-4 $\left(\delta_{\mathrm{C}} 76.3\right)$ positions were deduced from the ${ }^{1} \mathrm{H}$ NMR $\left[\delta_{\mathrm{H}} 2.84(1 \mathrm{H}, \mathrm{d}, J=7.2 \mathrm{~Hz}\right.$, $\mathrm{OH}-2), 4.40(1 \mathrm{H}, \mathrm{d}, J=3.0 \mathrm{~Hz}, \mathrm{OH}-4)]$ and ${ }^{13} \mathrm{C}$ NMR $\left[\delta_{\mathrm{C}} 69.0(\mathrm{C}-2), 76.3\right.$ (C-4)] data in combination with the ${ }^{1} \mathrm{H}-{ }^{1} \mathrm{H}$ COSY $\left[\mathrm{OH}-2 / \mathrm{H}-2\left(\delta_{\mathrm{H}} 3.88\right)\right.$ and $\left.\mathrm{OH}-4 / \mathrm{H}-4\left(\delta_{\mathrm{H}} 3.78\right)\right]$ and $\mathrm{HMBC}\left[\mathrm{OH}-2 / \mathrm{C}-1\left(\delta_{\mathrm{C}} 44.2\right)\right.$, $\mathrm{C}-3\left(\delta_{\mathrm{C}} 58.4\right)$ and $\left.\mathrm{OH}-4 / \mathrm{C}-3, \mathrm{C}-5\left(\delta_{\mathrm{C}} 45.5\right)\right]$ experiments. Therefore, the planar structure of compound 1 was constructed. 
The ${ }^{13} \mathrm{C}$ NMR data of the ring A, coupling constants of $\mathrm{H}-2, \mathrm{H}-3$ and $\mathrm{H}-4$ and NOESY data clearly indicated that compound 1 differs from the previously reported compounds of hookerianamide $\mathrm{M}$ [10] and sarcovagine $\mathrm{A}$ [18] with respect to the stereochemistry at C-2, C-3, and C-4 positions. In the ROESY spectrum (Figure 2), the correlations of $\mathrm{H}-19\left[\delta_{\mathrm{H}} 1.21(3 \mathrm{H}, \mathrm{s})\right]$ with $\mathrm{OH}-2$ and $\mathrm{OH}-4$ indicated the $\beta$ orientations of the two hydroxyl groups. Furthermore, the obvious ROESY correlations (Figure 2) of $\mathrm{HN}$ with $\mathrm{H}-2, \mathrm{H}-4$ and $\mathrm{H}-5\left[\delta_{\mathrm{H}} 1.26(1 \mathrm{H}, \mathrm{m})\right]$ implied the $\alpha$ orientation of the tigloylamide group. The ring A of compound 1 may exist mainly as a stable boat conformation due to the substitution of $3 \alpha$ tigloylamide group [17]. Consequently, the structure and relative configuration of compound 1 was determined as (20S)-20- $N, N$-dimethylamino- $2 \beta, 4 \beta$-dihydroxyl- $3 \alpha$-tigloylamino- $5 \alpha$-pregnane, which was named sarchookloide A (Figure 1).

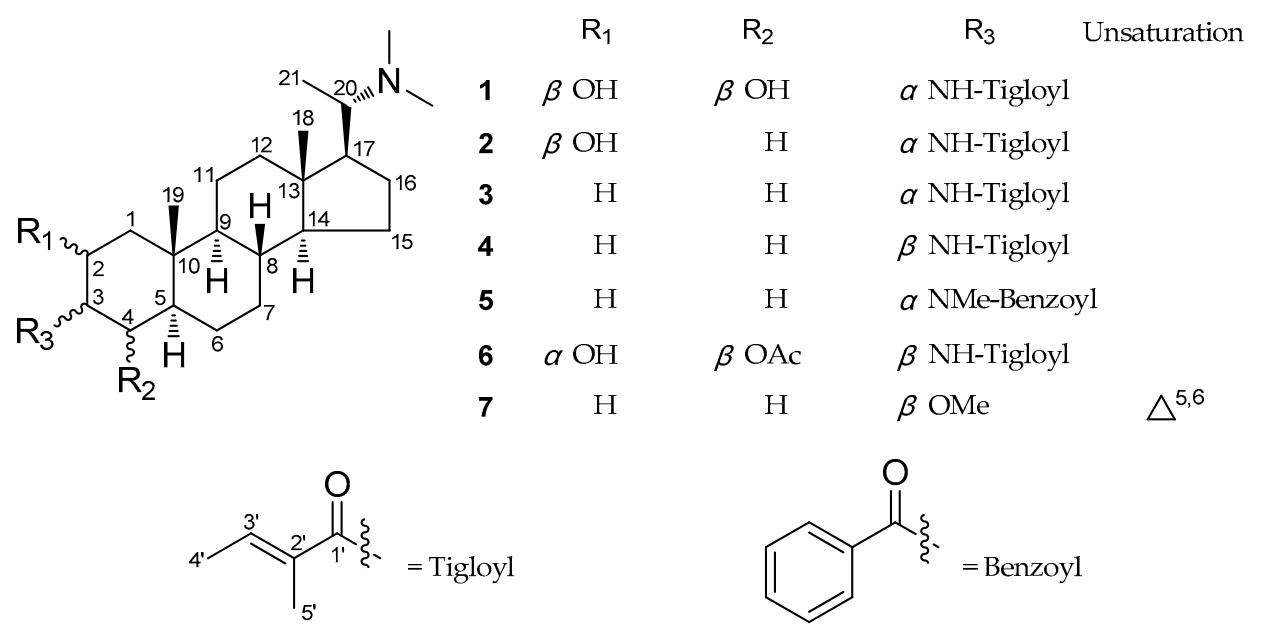

Figure 1. Structures of compounds 1-7.

Compound 2 had a molecular formula of $\mathrm{C}_{28} \mathrm{H}_{48} \mathrm{~N}_{2} \mathrm{O}_{2}$, which was determined by HR-ESI-MS $(\mathrm{m} / \mathrm{z}$ $\left.445.3775[\mathrm{M}+\mathrm{H}]^{+}\right)$, suggesting six degrees of unsaturation. The IR spectrum displayed absorptions indicating a hydroxyl group $\left(3443 \mathrm{~cm}^{-1}\right)$, amide carbonyl group $\left(1664 \mathrm{~cm}^{-1}\right)$ and double bond $(1629$ $\mathrm{cm}^{-1}$ ). In the ${ }^{13} \mathrm{C}$ NMR and DEPT spectra (Table 1), 28 carbon signals were observed, including 23 carbon resonances assigned to a $20 \alpha$-dimethylamino-3-amino-5 $\alpha$-pregnane type steroidal alkaloid skeleton and 5 carbon resonances for a tigloyl group [21]. The ${ }^{1} \mathrm{H}-{ }^{1} \mathrm{H}$ COSY correlated signal of $\mathrm{H}-4^{\prime}$ $\left[\delta_{\mathrm{H}} 1.75(3 \mathrm{H}, \mathrm{d}, J=6.9 \mathrm{~Hz})\right] / \mathrm{H}-3^{\prime}\left[\delta_{\mathrm{H}} 6.37(1 \mathrm{H}, \mathrm{q}, J=6.9 \mathrm{~Hz})\right]$ and the HMBC correlations of $\mathrm{H}-5^{\prime}$ $\left[\delta_{\mathrm{H}} 1.84(1 \mathrm{H}, \mathrm{s})\right] / \mathrm{C}-3^{\prime}\left[\delta_{\mathrm{C}} 130.8\right], \mathrm{C}-1^{\prime}\left[\delta_{\mathrm{C}} 169.2\right], \mathrm{H}-3^{\prime} / \mathrm{C}-1^{\prime}$ and $\mathrm{HN}\left[\delta_{\mathrm{H}} 5.82(1 \mathrm{H}, \mathrm{d}, J=7.4 \mathrm{~Hz})\right] / \mathrm{C}-1^{\prime}$ (Figure 2) suggested that the tigloyl group were attached to N-3. The COSY correlations of $\mathrm{H}-2\left[\delta_{\mathrm{H}}\right.$ $3.97(1 \mathrm{H}, \mathrm{brs})] / \mathrm{H}-1\left[\delta_{\mathrm{H}} 1.16,1.87(2 \mathrm{H}, \mathrm{m})\right], \mathrm{H}-3\left[\delta_{\mathrm{H}} 4.03(1 \mathrm{H}, \mathrm{m})\right]$ proposed that the location of the hydroxyl group was at $\mathrm{C}-2$.

The similarity of the NMR data of compounds 2 and $20 \alpha$-dimethylamino- $2 \alpha$-hydroxyl$3 \beta$-tigloylamino- $5 \alpha$-pregnane [16] suggested that they possessed the same planar structure. The ROESY correlations (Figure 2) of $\mathrm{HN}$ with $\mathrm{H}-2$ and $\mathrm{H}-5\left[\delta_{\mathrm{H}} 1.07(1 \mathrm{H}, \mathrm{m})\right]$ implied the $\alpha$ orientation of the tigloylamide group and the $\beta$ orientation of the hydroxyl group. This was also supported by the discrepant $\mathrm{W}_{1 / 2}$ (14.8) of $\mathrm{H}-2$ [10] and the ${ }^{13} \mathrm{C}$ NMR data of the ring $\mathrm{A}$ in 2 compared with the data of reported compounds [16]. The substitution of $3 \alpha$ tigloylamide group led to the main boat conformation of the ring A in compound 2 . Consequently, the structure and relative configuration of compound 2 was determined as (20S)-20- $N, N$-dimethylamino-2 $\beta$-hydroxyl-3 $\alpha$-tigloylamino- $5 \alpha$-pregnane, which was named sarchookloide B (Figure 1).

Compound 3 was given the molecular formula $\mathrm{C}_{28} \mathrm{H}_{48} \mathrm{~N}_{2} \mathrm{O}$ according to its HR-ESI-MS data at $m / z 429.3829[\mathrm{M}+\mathrm{H}]^{+}$(calculated as 429.3839), corresponding to six degrees of unsaturation. The IR spectrum of compound 3 included the absorption bands for amide carbonyl group $\left(1665 \mathrm{~cm}^{-1}\right)$ and double bond $\left(1625 \mathrm{~cm}^{-1}\right)$. The ${ }^{13} \mathrm{C}$ NMR and DEPT spectra (Table 1 ) of compound 3 exhibited 28 carbon 
signals corresponding to four quaternary carbons, eight methines, nine methylene, and seven methyl groups, of which 23 carbon resonances were ascribed to $20 \alpha$-dimethylamino-3-amino-5 $\alpha$-pregnane type steroidal alkaloid skeleton and five carbon resonances were attributed to a tigloyl group [21].

Compound 3 and pachysamine G [19] exhibited the same planar structure, which was supported by the similar NMR data found for both of them. The $\alpha$-orientations of the tigloylamide group was assigned by the ROESY correlations (Figure 2) of $\mathrm{HN}\left[\delta_{\mathrm{H}} 5.93(1 \mathrm{H}, \mathrm{d}, J=6.6 \mathrm{~Hz})\right]$ with $\mathrm{H}-5\left[\delta_{\mathrm{H}} 1.11\right.$ $(1 \mathrm{H}, \mathrm{m})]$ in combination with the different shift of the ring A in compound 3 compared with the data of pachysamine $\mathrm{G}$ in ${ }^{13} \mathrm{C}$ NMR spectrum. Similar to compounds $\mathbf{1}$ and $\mathbf{2}$, the boat conformation of the ring $\mathrm{A}$ in compound 3 was the main conformation [17]. Therefore, the structure and relative configuration of compound 3 was determined as (20S)-20- $N, N$-dimethylamino- $3 \alpha$-tigloylamino- $5 \alpha$-pregnane, which was named sarchookloide C (Figure 1).

The known compounds 4-7 were identified as pachysamine G (4) [19], pachysamine H (5) [19], sarcovagine B (6) [18], and pachyaximine A (7) [20] through a comparison of their spectroscopic data with those reported in the literature.

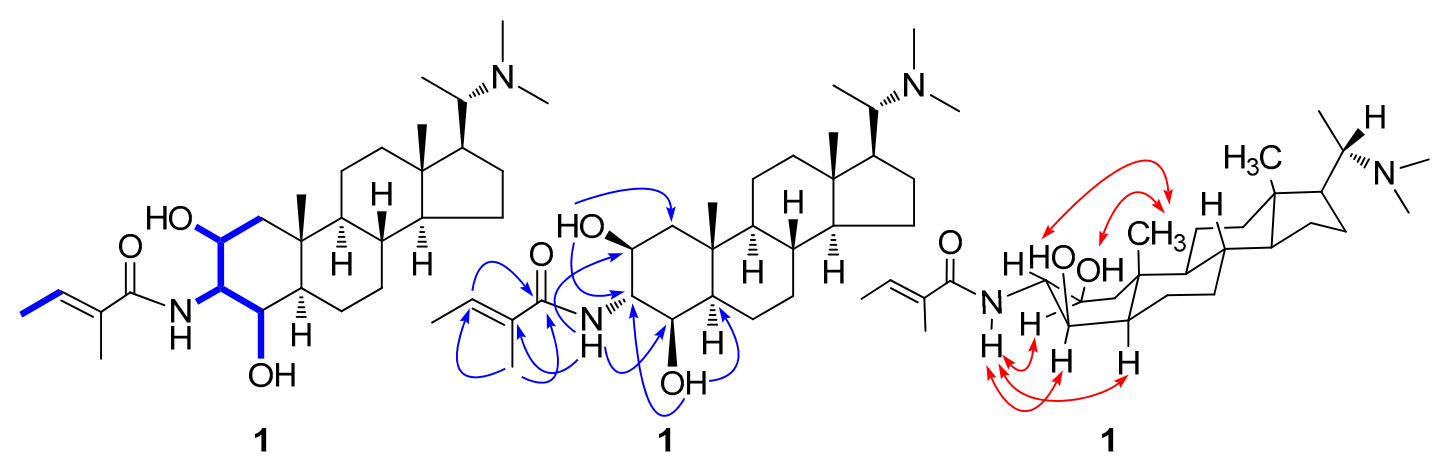

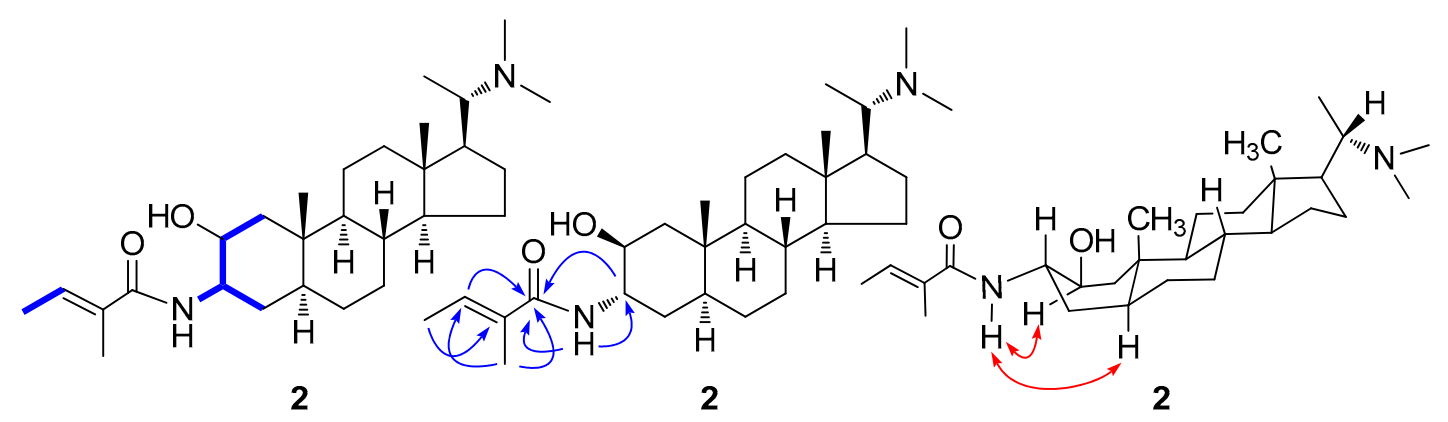

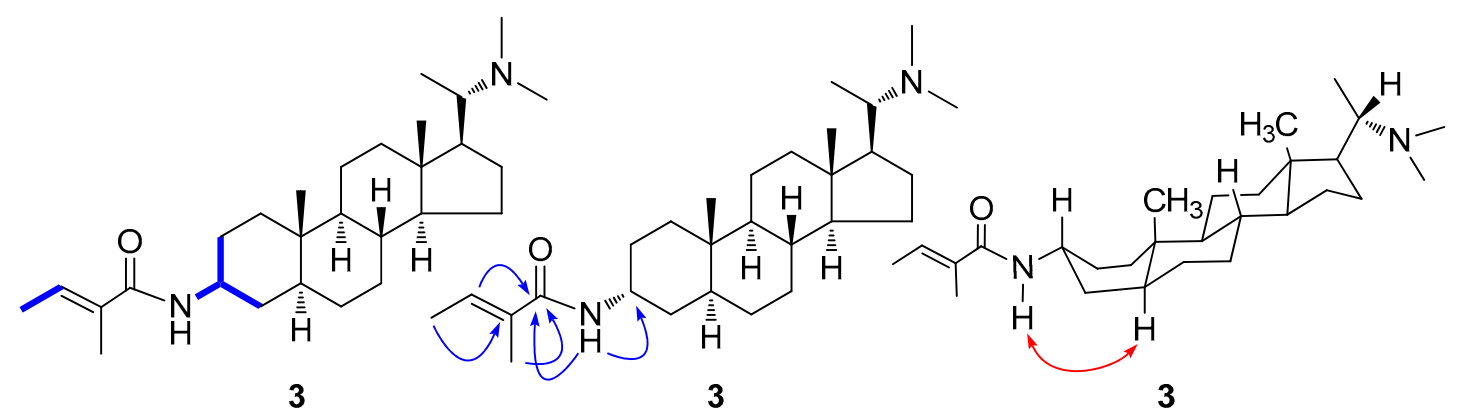

Figure 2. Key 1H-1H COSY (-), HMBC $(\rightarrow)$ and ROESY $(\leftrightarrow)$ correlations of compounds 1-3.

\subsection{Results of the Cytotoxicity Test}

All compounds were evaluated using a MTT cytotoxicity assay against human cervical cancer cell line Hela, lung adenocarcinoma cell line A549, breast cancer cell line MCF-7, colon cancer cell line SW480, and leukemia CEM cells (adriamycin was used as the positive control). The $\mathrm{IC}_{50}$ values of 
all compounds against the indicated cancer cells are summarized in Table 2. Compound 5 had the greatest cytotoxicity to all cells, as its range of $\mathrm{IC}_{50}$ values was approximately $1.05-2.23 \mu \mathrm{M}$. All three amide-substituted compounds, except for pachyaximine A, exhibited significant cytotoxic activity on all cells, which suggests that the amide group of these compounds was the necessary group for the cytotoxicity. In addition, Hela and A549 were the more sensitive cell lines to these types of compounds compared to all tested cancer cells because the $\mathrm{IC}_{50}$ values of all compounds were less than $10 \mu \mathrm{M}$. Furthermore, all active compounds showed effects that were comparable to the chemotherapeutic drug adriamycin in inhibiting the growth of all cancer cells, which suggests that three amide-substituted pregnane-type steroidal alkaloids might have the potential to be anticancer agents.

Table 2. Cytotoxicity of compounds $1-7^{\text {a }}$ against Hela, A549, MCF-7, SW480, and CEM cells in vitro $\left(\mathrm{IC}_{50} \mathrm{~b}, \mu \mathrm{M}\right)$.

\begin{tabular}{cccccc}
\hline \multirow{2}{*}{ Compounds } & \multicolumn{5}{c}{ Cell Lines } \\
\cline { 2 - 6 } & Hela & A549 & MCF-7 & SW480 & CEM \\
\hline $\mathbf{1}$ & $4.13 \pm 0.14$ & $2.53 \pm 0.15$ & $4.47 \pm 0.06$ & $6.42 \pm 0.10$ & $4.26 \pm 0.11$ \\
$\mathbf{2}$ & $7.93 \pm 0.09$ & $8.73 \pm 0.16$ & $28.53 \pm 0.17$ & $8.97 \pm 0.10$ & $31.83 \pm 0.25$ \\
$\mathbf{3}$ & $1.24 \pm 0.10$ & $2.87 \pm 0.14$ & $2.53 \pm 0.12$ & $3.08 \pm 0.14$ & $3.43 \pm 0.13$ \\
$\mathbf{4}$ & $2.43 \pm 0.11$ & $2.98 \pm 0.17$ & $3.70 \pm 0.26$ & $26.04 \pm 0.21$ & $3.05 \pm 0.13$ \\
$\mathbf{5}$ & $1.06 \pm 0.14$ & $1.18 \pm 0.11$ & $2.23 \pm 0.15$ & $1.49 \pm 0.10$ & $1.05 \pm 0.06$ \\
$\mathbf{6}$ & $1.38 \pm 0.09$ & $4.96 \pm 0.12$ & $1.65 \pm 0.09$ & $3.76 \pm 0.14$ & $6.06 \pm 0.16$ \\
$\mathbf{7}$ & $>100$ & $>100$ & $>100$ & $>100$ & $>100$ \\
Adriamycin $^{\mathrm{c}}$ & $0.62 \pm 0.08$ & $0.77 \pm 0.06$ & $1.26 \pm 0.05$ & $1.19 \pm 0.11$ & $0.98 \pm 0.08$ \\
\hline
\end{tabular}

${ }^{a}$ All results are expressed as mean $\pm \mathrm{SD} ; n=3$ for all groups. ${ }^{\mathrm{b}} \mathrm{IC}_{50}: 50 \%$ inhibitory concentration. ${ }^{\mathrm{c}}$ Adriamycin was the positive control.

\section{Materials and Methods}

\subsection{General Experimental Procedures}

Optical rotations were obtained on a JASCO model 1020 polarimeter (Horiba, Tokyo, Japan). UV spectra were measured on a Shimadzu UV-2401PC spectrophotometer (Shimadzu, Kyoto, Japan). IR (KBr) spectra were measured on a Bio-Rad FTS-135 spectrometer (Bio-Rad, Hercules, CA, USA). The 1D and 2D NMR spectra were recorded on Bruker AVANCE III-600 spectrometers with TMS used as an internal standard (Bruker, Bremerhaven, Germany). The mass spectra were obtained on a Waters AutoSpec Premier P776 (Waters, NY, USA). The silica gel (200-300 mesh) for column chromatography and the TLC plates $\left(\mathrm{GF}_{254}\right)$ were obtained from Qingdao Marine Chemical Factory (Qingdao, Shandong, China). The Sephadex LH-20 (20-150 $\mu \mathrm{m})$ used for chromatography was purchased from Pharmacia Fine Chemical Co. Ltd. (Pharmacia, Uppsala, Sweden). Fractions were visualized by heating silica gel plates sprayed with Dragendorff's reagent. The cell lines Hela, A549, MCF-7, SW480, and CEM were obtained from the Cell Bank of the Chinese Academy of Sciences (Shanghai, China), while MTT were obtained from Sigma Company.

\subsection{Plant Material}

The plants of Sarcococca hookeriana Baill. were collected in Hezhang County, Guizhou Province, China, in April 2012 and identified by Prof. Qingwen Sun, Guiyang College of Traditional Chinese Medicine. A voucher specimen (No. 20120401401) was deposited at the Key Laboratory of Miao Medicine of Guizhou Province, Guiyang College of Traditional Chinese Medicine.

\subsection{Extraction and Isolation}

The air-dried and powdered roots of S. hookeriana Baill. $(2.5 \mathrm{~kg})$ were extracted with $95 \%(25 \mathrm{~L})$ $\mathrm{EtOH}$ under reflux three times, with an extraction time of $2 \mathrm{~h}$. The combined extracts $(443 \mathrm{~g})$ were concentrated and suspended in $\mathrm{H}_{2} \mathrm{O}(3 \mathrm{~L})$. The suspension was extracted with $\mathrm{CHCl}_{3}$ to obtain the 
$\mathrm{CHCl}_{3}$ fraction (94 g). The $\mathrm{CHCl}_{3}$ fraction was subjected to silica gel column chromatography (Si CC) and eluted with petroleum ether-diethylamine (100:1, 95:5, 9:1, 8:2) to yield four fractions (Fractions A-D). Fraction B (1.6 g) was subjected to Si CC and eluted with petroleum ether-diethylamine (100:2, 9:1) to yield the fractions B1-B3. Fraction B2 $(330 \mathrm{mg})$ was chromatographed using Si CC and was developed with petroleum ether-diethylamine (100:2) to yield compounds 3 (21 $\mathrm{mg}$ ) and 4 (35 mg). Si CC was performed on Fraction C (12.3 g) with a gradient eluent of petroleum ether-diethylamine $(100: 5,9: 1,8: 2)$ to yield four fractions (fractions C1-C4). Fraction C2 (1.4 g) was first subjected to Si CC (petroleum ether-diethylamine, 100:5), before being purified on Sephadex LH-20. This yielded compounds 2 (26 mg), 5 (30 mg) and 7 (31 mg). Fraction C4 (985 mg) was purified on Sephadex LH-20, before Si CC was used (petroleum ether-diethylamine, 9:1) to separate compounds $\mathbf{1}(33 \mathrm{mg})$ and $\mathbf{6}$ (19 mg).

\subsubsection{Sarchookloide A (1)}

This was a white amorphous powder with a HR-ESI-MS $m / z$ of $461.3731[\mathrm{M}+\mathrm{H}]^{+}$(calculated for $\mathrm{C}_{28} \mathrm{H}_{49} \mathrm{~N}_{2} \mathrm{O}_{3}, 461.3738$ ). The $[\alpha]_{D}^{22}$ was +52.99 (c 0.58, MeOH); $\mathrm{UV}(\mathrm{MeOH})$ had a $\lambda_{\max }$ of $209.4 \mathrm{~nm}$; and IR (KBr) had a $v_{\max }$ of 3424,2931, 2867, 1662 and $1623 \mathrm{~cm}^{-1}$. The ${ }^{1} \mathrm{H}$ and ${ }^{13} \mathrm{C}$ NMR data are shown in Table 1.

\subsubsection{Sarchookloide B (2)}

This was a white amorphous powder with a HR-ESI-MS $m / z$ of $445.3775[\mathrm{M}+\mathrm{H}]^{+}$(calculated for $\left.\mathrm{C}_{28} \mathrm{H}_{49} \mathrm{~N}_{2} \mathrm{O}_{2}, 445.3789\right)$. The $[\alpha]_{D}^{22}$ was $+30.18(c 0.57, \mathrm{MeOH})$; $\mathrm{UV}(\mathrm{MeOH})$ had a $\lambda_{\max }$ of $205.8 \mathrm{~nm}$; and IR (KBr) had a $v_{\max }$ of $3442,2930,2966,1664$ and $1629 \mathrm{~cm}^{-1}$. The ${ }^{1} \mathrm{H}$ and ${ }^{13} \mathrm{C}$ NMR data are shown in Table 1.

\subsubsection{Sarchookloide C (3)}

This was a white amorphous powder with a HR-ESI-MS $m / z$ of $429.3829[\mathrm{M}+\mathrm{H}]^{+}$(calculated for $\mathrm{C}_{28} \mathrm{H}_{49} \mathrm{~N}_{2} \mathrm{O}$, 429.3839). The $[\alpha]_{D}^{22}$ was +7.10 (c 0.62, MeOH); $\mathrm{UV}(\mathrm{MeOH})$ had a $\lambda_{\max }$ of $207.2 \mathrm{~nm}$; and IR (KBr) had a $v_{\max }$ of $3454,2930,2853,1665$ and $1625 \mathrm{~cm}^{-1}$. The ${ }^{1} \mathrm{H}$ and ${ }^{13} \mathrm{C}$ NMR data are shown in Table 1.

\subsection{Cytotoxicity Assay}

The cytotoxicity of compounds 1-7 was tested on the human cervical cancer cell line Hela, lung adenocarcinoma cell line A549, breast cancer cell line MCF-7, colon cancer cell line SW480 and leukemia CEM cells. All cells were cultured in a RPMI-1640 or DMEM medium (Hyclone, Logan, UT, USA), which was supplemented with $10 \%$ fetal bovine serum (Hyclone) in $5 \% \mathrm{CO}_{2}$ at $37^{\circ} \mathrm{C}$. The cytotoxicity assay was performed using the MTT method in 96-well microplates [22]. Briefly, the adherent cells $(100 \mu \mathrm{L})$ were seeded into each well of 96-well cell culture plates and allowed to adhere for $12 \mathrm{~h}$ before the addition of the drug. The suspended cells were seeded just before the addition of the drug at an initial density of $1 \times 10^{5}$ cells $/ \mathrm{mL}$. Each tumor cell line was exposed to the tested compound at different concentrations for $48 \mathrm{~h}$. The experiments were performed in triplicate. Adriamycin (Sigma, St. Louis, MO, USA) was used as a positive control. After treatment, cell viability was measured and the cell growth curve was plotted. The $\mathrm{IC}_{50}$ values were calculated by the Reed and Muench method [23].

\section{Conclusions}

We obtained three new pregnane-type steroidal alkaloids, sarchookloides A-C (1-3), along with four known compounds, pachysamine $G(4)$, pachysamine $H(5)$, sarcovagine $B(6)$, and pachyaximine A (7), from the roots of Sarcococca hookeriana. The new compounds, sarchookloides A-C (1-3), were shown to possess a $3 \alpha$ substituent, which has rarely been reported. By performing a cytotoxic 
assay on Hela, A549, MCF-7, SW480 and CEM cell lines in vitro, all three amide substituted compounds exhibited significant cytotoxic activities on all cells, which suggests that the three amide group of these compounds was the necessary group for the cytotoxicity. The most active compound, pachysamine $\mathrm{H}$ (5), inhibited all cancer cells with $\mathrm{IC}_{50}$ values in the range of approximately $1.05-2.23 \mu \mathrm{M}$. The results suggested that these types of steroidal alkaloids merit further biological evaluation of their cytotoxic activities and might have the potential to be studied for anticancer activity.

Supplementary Materials: The following ${ }^{1} \mathrm{H}$ NMR, ${ }^{13} \mathrm{C}$ NMR, 2D NMR, HR-ESI-MS spectra and the RAW data of the new compounds are available as supporting data. Supplementary materials are available online.

Author Contributions: K.H. and J.D. designed the experiments and revised the paper; K.H. and J.W. performed the experiments, analyzed the data, and wrote the paper; J.W. and J.Z. contributed to bioassay reagents and materials and analyzed the data; J.W., S.H. and J.D. revised the paper. All authors read and approved the final manuscript.

Acknowledgments: This research work was financially supported by the Science and Technology Foundation of Guizhou Province [grant number J (2013) 2071], the Science and Technology Cooperation Program of Guizhou Province [grant number LH (2015) 7277], the Youth Science and Technology Talent Project of Guizhou Province [grant number (2017) 5618], and the Open Project of the Key Laboratory of Miao Medicine of Guizhou Province [grant number K (2017) 004].

Conflicts of Interest: We wish to confirm that there are no known conflicts of interest associated with this publication and that there has been no significant financial support for this work that could have influenced its outcome.

\section{References}

1. Editorial Committee of Flora of China. Flora Reipublicae Popularis Sinicae; Science Press: Beijing, China, 2004; Volume 45, pp. 41-56.

2. Editorial Committee of Zhong Hua Ben Cao. Zhong Hua Ben Cao; Shanghai Scientific and Technological Press: Shanghai, China, 1999; Volume 13, pp. 224-227.

3. Zhang, Y.Y.; Li, T.Y.; Tang, F.; Yang, L.N. Parmacodynamics study in Li medicine plants Sarcococca vagans Stapf. Chin. J. Ethnomed. Ethnopharm. 2016, 26, 46-48.

4. Li, H.C.; Yang, J.; Yuan, D.P.; Liu, Y. Advances in studies on chemical constituents in plants of Sarcococca hookeriana and their biological activities. Lishizhen Med. Mater. Med. Res. 2016, 27, 1711-1713.

5. Ullah Jan, N.; Ali, A.; Ahmad, B.; Iqbal, N.; Adhikari, A.; Inayat Ur, R.; Musharraf, S.G. Evaluation of antidiabetic potential of steroidal alkaloid of Sarcococca saligna. Biomed. Pharmacoth. 2018, 100, 461-466.

6. Zhang, P.; Shao, L.; Shi, Z.; Zhang, Y.; Du, J.; Cheng, K.; Yu, P. Pregnane alkaloids from Sarcococca ruscifolia and their cytotoxic activity. Phytochem. Lett. 2015, 14, 31-34. [CrossRef]

7. Adhikari, A.; Vohra, M.I.; Jabeen, A.; Dastagir, N.; Choudhary, M.I. Antiinflammatory steroidal alkaloids from Sarcococca wallichii of Nepalese origin. Nat. Prod. Commun. 2015, 10, 1533-1536.

8. Zhang, P.Z.; Wang, F.; Yang, L.J.; Zhang, G.L. Pregnane alkaloids from Sarcococca hookeriana var. digyna. Fitoterapia 2013, 89, 143-148. [PubMed]

9. Yan, Y.X.; Sun, Y.; Chen, J.C.; Wang, Y.Y.; Li, Y.; Qiu, M.H. Cytotoxic steroids from Sarcococca saligna. Planta Med. 2011, 77, 1725-1729. [CrossRef] [PubMed]

10. Devkota, K.P.; Wansi, J.D.; Lenta, B.N.; Khan, S.; Choudhary, M.I.; Sewald, N. Bioactive steroidal alkaloids from Sarcococca hookeriana. Planta Med. 2010, 76, 1022-1025. [CrossRef] [PubMed]

11. Choudhary, M.I.; Adhikari, A.; Samreen; Atta Ur, R. Antileishmanial steroidal alkaloids from roots of Sarcococca coriacea. J. Chem. Soc. Pakistan 2010, 32, 799-802.

12. Devkota, K.P.; Lento, B.N.; Wansi, J.D.; Choudhary, M.I.; Sewald, N. Cholinesterase inhibiting, antileishmanial and antiplasmodial steroidal alkaloids from Sarcococca hookeriana of Nepalese origin. Planta Med. 2008, 74, 979. [CrossRef]

13. Devkota, K.P.; Lenta, B.N.; Wansi, J.D.; Choudhary, M.I.; Kisangau, D.P.; Naz, Q.; Sewald, N. Bioactive 5 alpha-pregnane-type steroidal alkaloids from Sarcococca hookeriana. J. Nat. Prod. 2008, 71, 1481-1484. [CrossRef] [PubMed] 
14. Devkota, K.P.; Lenta, B.N.; Choudhary, M.I.; Naz, Q.; Fekam, F.B.; Rosenthal, P.J.; Sewald, N. Cholinesterase inhibiting and antiplasmodial steroidal alkaloids from Sarcococca hookeriana. Chem. Pharm. Bull. 2007, 55, 1397-1401. [CrossRef] [PubMed]

15. Devkota, K.P.; Choudhary, M.I.; Ranjit, R.; Samreen; Sewald, N. Structure activity relationship studies on antileishmanial steroidal alkaloids from Sarcococca hookeriana. Nat. Prod. Res. 2007, 21, 292-297. [CrossRef] [PubMed]

16. He, K.; Du, J. Two new steroidal alkaloids from the roots of Sarcococca ruscifolia. J. Asian Nat. Prod. Res. 2010, 12, 233-238. [CrossRef] [PubMed]

17. Qiu, M.H.; Nie, R.L.; Li, Z.R. Chemical structure and activity screening of pachysandra alkaloids. Acta Bot. Yunnanica 1994, 16, 296-300.

18. Yu, S.S.; Zou, Z.M.; Zen, J.; Yu, D.Q.; Cong, P.Z. Four new steroidal alkaloids from the roots of Sarcococca vagans. Chin. Chem. Lett. 1997, 8, 511-514.

19. Qiu, M.H.; Nie, R.L.; Li, Z.R.; Zhou, J. Three new steroidal alkaloids from Pachysandra axillaris. Acta Bot. Sin. 1990, 32, 626-630.

20. Naeem, I.; Khan, N.; Choudhary, M.I.; Rahman, A. Alkaloids of Sarcococca saligna. Phytochemistry 1996, 43, 903-906. [CrossRef]

21. Qiu, M.H.; Wang, D.Z.; Nie, R.L. Study on ${ }^{13}$ C NMR of pachysandra alkaloids. Chin. J. Magn. Reson. 1995, 12, 155-165.

22. Mosmann, T. Rapid colorimetric assay for cellular growth and survival: Application to proliferation and cytotoxicity assays. J. Immunol. Methods 1983, 65, 55-63. [CrossRef]

23. Reed, L.J.; Muench, H. A simple method of estimating fifty percent endpoint. Am. J. Hyg. 1938, $27,493-497$.

Sample Availability: Samples of the compounds 1-7 are available from the authors.

(C) 2018 by the authors. Licensee MDPI, Basel, Switzerland. This article is an open access article distributed under the terms and conditions of the Creative Commons Attribution (CC BY) license (http:// creativecommons.org/licenses/by/4.0/). 